\title{
In Memoriam: Haig H. Kazazian, Jr. (1937-2022)
}

\author{
Garry Cutting ${ }^{1}$ \\ ${ }^{1}$ Johns Hopkins University School of Medicine
}

February 7, 2022

\begin{abstract}
With great sadness, we report that Haig Kazazian, Founding Co-Editor of Human Mutation, died on January 19,2022 of complications related to congestive heart failure.
\end{abstract}

In Memoriam: Haig H. Kazazian, Jr. (1937-2022)

Garry R. Cutting

Editor, Human Mutation

Department of Genetic Medicine, Johns Hopkins University School of Medicine, Baltimore, Maryland

With great sadness, we report that Haig Kazazian, Founding Co-Editor ofHuman Mutation, died on January 19, 2022 of complications related to congestive heart failure. We extend our condolences to his wife Lilli and his children Haig III and Sonya and their families.

Haig spent his entire career passionately devoted to human genetics. He spent most of his academic life at Johns Hopkins, starting with Medical School then Pediatric Residency followed by training in genetics with Barton Childs. In addition to running a highly productive research program, Haig oversaw the formation of the Center for Medical Genetics that combined the Pediatric and Adult genetics units at Hopkins. Haig was a prolific mentor, overseeing the successful transition of dozens of fellows and graduate students to independent researchers. Two autobiographic reviews detail Haig's contributions and illustrate his infectious enthusiasm for science (Kazazian, 2017; Kazazian, 2021).

Human Mutation owes its existence to an outstanding partnership between Haig and Richard "Dick" Cotton. Both were keenly interested in the detection of DNA variants associated with human disease, leading to the formation of this journal in 1992. The concept of a journal dedicated to the discovery of human variants and their functional and clinical implications was prescient. Over the 30 years of its existence (and counting), Human Mutation has witnessed an explosion in variant detection, from the almost universal adoption of the PCR methods in research and clinical labs, to the broad implementation of next-generation sequencing, the proliferation of variant databases and to the growth of clinical molecular genetic testing into a multi-billion dollar industry. Haig was delighted with the success of Human Mutation as documented in a Special Issue commemorating the $25^{\text {th }}$ anniversary of the journal. (Cutting and Kazazian, 2016). The issue was dedicated to Dick Cotton, who had died in the previous year.

Haig's lifelong commitment to mentoring underlies my current appointment as Editor of the journal. I had just begun my independent research career at Hopkins after a highly fulfilling postdoc with Haig. As he has done for many others, Haig gave me an early career stage opportunity to mature my approach to science while increasing my visibility at an international level by inviting me to be a Communicating Editor for the journal. Haig always made time to advise me regarding the merit, or in some cases, lack of merit in a manuscript and recommend how to reconcile divergent reviewer opinions. On these occasions, Haig would 
never fail to ask me how my research was going, what I found interesting of late, and to encourage me to persevere when I hit a wall in the lab, in funding or in the publishing arena. I will also be forever grateful for Haig's unwavering confidence in me, particularly in his providing me the opportunity to succeed him on study sections, national committees and as a Co-Editor of this journal. Haig's tireless promotion of his former trainees and willingness to make time for anyone who had a scientific question throughout his career provided a role model that many are striving to emulate.

In the later phase of his career, Haig assumed the Chair of the Department of Genetics at the University of Pennsylvania School of Medicine, a position he held for 12 years before returning to Hopkins to focus on his research in transposable elements. Arupa Ganguly, PhD, Professor of Genetics and Director of the Genetic Diagnostic Laboratory at the University of Pennsylvania, provided comments reflecting Haig's time at UPenn:

I first met Haig 29 years ago at a Human Mutation Detection meeting in Turin, Italy. That encounter took me in the direction of defining molecular genetic causes of human diseases, including breast cancer genes, as my career path for the last three decades. He asked me to join the journal as a Communicating Editor in 2003, which has continued to this day. It has been a very fulfilling and rewarding experience that I will cherish forever. I have also had the privilege of riding on a unique journey with Haig in the realm of Gene Patenting while he was at Penn. Haig and I were the lead co-plaintiffs in the now famous case of ACLU versus Myriad Genetics in 2008. I sat next to him inside the Supreme Court on the day of deliberations in April, 2013 and we celebrated together the unanimous decision that genes cannot be patented in June, 2013. At Penn, Haig hired a whole generation of junior faculty members whose careers have matured into big scientific success stories. One of his main contributions was to build bridges between basic scientists at Penn with clinical human geneticists at Children's Hospital of Philadelphia. This effort resulted in many successful collaborations including training multiple physician scientists who have gone on to be leaders in many different organizations. His scientific curiosity compelled him to always ask questions and raise intriguing thoughts at every meeting he attended - be it departmental Journal Club or the American Society of Human Genetics annual meetings. His friends and colleagues at the department at Penn deeply felt his absence after he left for Johns Hopkins. We all missed the casual encounters with him as he walked into our offices which often led to long discussions on science, how to teach medical genetics, empathy for immigrant colleagues, students, and post-docs and, above all, life and family. I saw his biggest smile when his grandson unveiled his photograph that adorns the wall of Clinical Research Building Lobby.

Arupa's sentiments and those of her colleagues at Penn encompass themes repeated by faculty at Johns Hopkins and among the Editorial Board of this journal. Mark H. Paalman, PhD, Publisher of Molecular Medicine and Genetics at Wiley, offered comments from the publisher's perspective:

On its founding in 1992, Human Mutation was conceived with both patient-oriented and functional aspects of human molecular genetics in mind. Haig, a renowned research clinician, collaborated with technical scientist Richard "Dick" Cotton to lead the journal with a yin-yang of application and innovation for fifteen years. They were dedicated to making their journal relevant beyond just citations and downloads. In fact, I'd argue that Haig and Dick anticipated the present era of open science. In the late 1990s, they launched a section of free online-only articles years before "open access" exploded. In the early 2000s, they insisted on making the novel genetic variation data they published freely available through public databases. As their managing editor and publisher, it was all I could do to keep up with them as they pushedHuman Mutation into the future! The editorial and scientific success of Haig was not achieved at the expense of others. For me, Haig will forever remain an exemplar of the best type of scientist-editor: one who, while forward thinking, does not lose sight of the present and those within it. Evident at every encounter was his engagement, with not only the science but, more importantly, with the people behind it. Haig would urge the editorial board toward excellence, but not merely in pursuit of an Impact Factor. He was not an editor who ticked the boxes and processed the papers. He was all about inspiring those with whom he worked. For the journal, this meant cultivating relationships with not just the editors and reviewers and office staff, but also the authors. Haig was among the most sincere, honest, and approachable scientists I have ever known, never too busy 
to answer a question or to suggest an approach. After he retired as Co-Editor in 2007, he stayed on as a Communicating Editor and continued, gently, to assist where needed and advise if asked. Along with Haig's numerous acquaintances over the years at Wiley, I am so grateful for having had the opportunity to walk a bit of this earth with him.

We thank Haig for his friendship, warmth and support. Maintaining his spark of curiosity and passing it to future generations would be a fitting way to commemorate Haig's life.

\section{REFERENCES}

Cutting GR and Kazazian HH. 2016. 25 Years of Human Mutation. Human Mutation 37:503-504. doi/10.1002/humu.22988

Kazazian HH. 2017. Fifty Years in Human Genetics - A Career Retrospective. FASEB Journal 31:3712-3718. doi/full/10.1096/fj.201700502RR

Kazazian HH. 2021. A Long, Fulfilling Career in Human Genetics. Annual Review of Genomics and Human Genetics 22:27-53. doi/10.1146/annurev-genom-111620-095614

FIGURE

Portrait by Paul McGuirk Photography 